\title{
Limited Genetic Variability Among American Isolates of Grapevine virus $E$ from Vitis spp.
}

J. Vargas-Asencio, Department of Plant Pathology and Plant-Microbe Biology, Cornell University, Ithaca, NY 14853; M. Al Rwahnih and A. Rowhani, Department of Plant Pathology, University of California, Davis 95616; F. Celebi-Toprak, Department of Biology, Pamukkale University, Denizli, Turkey; J. R. Thompson, Department of Plant Pathology and Plant-Microbe Biology, Cornell University; M. Fuchs, Department of Plant Pathology, Cornell University, New York State Agricultural Experiment Station, Geneva, NY 14456; and K. L. Perry, Department of Plant Pathology and Plant-Microbe Biology, Cornell University

\begin{abstract}
Vargas-Asencio, J., Al Rwahnih, M., Rowhani, A., Celebi-Toprak, F., Thompson, J. R., Fuchs, M., and Perry, K. L. 2016. Limited genetic variability among American isolates of Grapevine virus E from Vitis spp. Plant Dis. 100:159-163.

A survey for the presence of Grapevine virus E (GVE, genus Vitivirus, family Betaflexiviridae) in vineyards in New York and California was conducted using macroarray hybridization or reverse-transcription polymerase chain reaction (RT-PCR) assays. In New York, GVE was detected in 10 of 46 vines of Vitis labrusca, one V. riparia, and one Vitis hybrid. All GVE-infected New York vines were coinfected with Grapevine leafroll-associated virus-3. In California, GVE was detected in 8 of 417 vines of $V$. vinifera. All GVE-infected California vines were also coinfected by one of the leafroll-associated viruses and other vitiviruses.

In order to assess the genetic diversity among GVE isolates, a viral cDNA was amplified by RT-PCR, and a 675-nucleotide region that included the $3^{\prime}$ terminus of the coat protein gene, a short intergenic region, and the $5^{\prime}$ terminus of the putative nucleic acid binding protein gene was sequenced. All $20 \mathrm{GVE}$ isolates sequenced in this study were very closely related, with $>98 \%$ nucleotide identity to the SA94 isolate from South Africa. These findings confirm the presence of GVE in major grapegrowing regions of the United States and indicate a very low level of genetic diversity.
\end{abstract}

Grapevine production is significantly compromised by virus infections, with resulting reductions in the quantity and quality of the crop (Komar et al. 2007; Martelli 2014). To date, 67 viruses have been reported to infect grapevines (Al Rwahnih et al. 2015; Maliogka et al. 2015; Martelli 2014). Four virus-associated disease complexes are of particular concern worldwide: (i) leafroll, (ii) infectious degeneration or decline, (iii) rugose wood, and (iv) fleck. The viruses associated with these diseases are, respectively: members of the genera Ampelovirus, Closterovirus, and Velarivirus in the family Closteroviridae (leafroll viruses) (Maree et al. 2013; Martelli et al. 2012); members of the genus Nepovirus (nematode-transmitted viruses) and Strawberry latent ringspot virus in the family Secoviridae (Martelli and Boudon-Padieu 2006); members of the genera Vitivirus and Foveavirus (rugose wood-associated viruses) in the family Betaflexiviridae (Rosa et al. 2011); and members of the genus Maculavirus, family Tymoviridae (fleck virus).

Viruses of the genus Vitivirus have gained attention in recent years, and there are five recognized vitiviruses associated with grapevine: Grapevine virus A (GVA), Grapevine virus B (GVB), Grapevine virus $D$, Grapevine virus $E$ (GVE), and Grapevine virus $F$ (du Preez et al. 2011; Martelli 2014). GVE was first reported associated with rugose wood symptoms in a Japanese grape cultivar in 2008 (Nakaune et al. 2008). Following this report, two new isolates were described along with their full-length sequences, one from South Africa (Coetzee et al. 2010b) and the other from the United States (Alabi et al. 2013). More recently, GVE was detected infecting grapevine in China (Fan et al. 2013) and several grapevine species in New York, including Vitis labrusca 'Concord' (Thompson et al. 2014). Although information about Concord-infecting viruses is limited, there

Corresponding author: K. L. Perry; E-mail: KLP3@ @ornell.edu

Accession numbers of submitted sequences: KR062097-KR062118

Accepted for publication 11 June 2015.

http://dx.doi.org/10.1094/PDIS-05-15-0556-RE

C 2016 The American Phytopathological Society are reports of many of the viruses associated with the major groups of grape diseases being detected in Concord vines (Bahder et al. 2013; Ramsdell et al. 1983; Soule et al. 2006; Thompson et al. 2014; Uyemoto et al. 1977). Based on our earlier findings and the small number of reports of GVE, a limited survey was initiated with the objectives of (i) assessing the occurrence of GVE in vines in New York and California and (ii) obtaining an estimate of the genetic diversity for this virus in North America. Because preliminary testing of Concord vines in New York had shown Grapevine leafroll associated virus-3 (GLRaV-3) to be present, the testing for this virus was an additional objective.

\section{Materials and Methods}

Sampling of grapevines. To determine the occurrence of GVE in North American vines, collections were made from six sites or regions (Table 1). In New York, samples of canes were taken from dormant vines without regard to symptoms. Samples from western New York (Chautauqua, Erie, and Ontario Counties) consisted of Concord vines collected from 16 different commercial production sites. Additional samples were obtained from the United States Department of Agriculture (USDA) National Plant Germplasm System, Plant Genetic Resources Unit in Geneva, NY. In order to determine the occurrence of GVE in California, samples were obtained from the USDA National Clonal Germplasm Repository in Winters, CA; the Davis Grapevine Virus Collection; the Foundation Plant Services collection; and commercial vineyards in Napa Valley, CA.

Virus detection. Two parallel surveys were undertaken, with the detection approaches taken in New York and California differing. To detect the presence of virus in cane samples from New York, a multiplex macroarray method was employed, as described (Thompson et al. 2014). Additionally, samples were specifically tested for GLRaV-3 by double-antibody sandwich enzyme-linked immunosorbent assay (ELISA) (Bioreba), and for GVE by reverse-transcription polymerase chain reaction (RT-PCR) using primers GVE-1-For and GVE-Rev for the amplification of a 992-bp fragment spanning open reading frame (ORF) 4 and 5 in the genome of the SA94 isolate (GenBank accession GU903012) (Coetzee et al. 2010b). For California samples, nucleic acid (NA) extracts were prepared from each of the grapevine samples as described by Al Rwahnih et al. (2014). About $0.2 \mathrm{~g}$ of frozen leaf petioles was homogenized using a HOMEX grinder (Bioreba) and 
NA extracts were prepared using a MagMAX-96 viral RNA isolation kit (Invitrogen) per the manufacturer's protocol. Extracted NA samples were analyzed for the presence of GVE by RT-PCR as described above. Samples were also tested for mixed infection with grapevine leafroll-associated viruses and vitiviruses by quantitative RT-PCR using TaqMan probes on the ABI 7900 HT Fast real-time PCR system (Invitrogen), as described previously (Klaassen et al. 2011).

Sequence analysis. To evaluate nucleotide diversity and look for evidence of selection pressures driving the evolution of GVE populations, a 675-nucleotide (nt) RT-PCR region from each isolate was sequenced using primers GVE-1-For and GVE-Rev (Coetzee et al. 2010b). To sequence isolates from New York, the PCR fragment was produced using AccuPrime Taq DNA Polymerase (Life Technologies) and directly sequenced using the amplification primers. For each sample, PCR products from two independent PCR experiments were sequenced and there were no discrepancies observed between sequences. For isolates from California, the amplified PCR products were analyzed by electrophoresis using a $1 \%$ agarose gel with Tris-acetate-EDTA buffer. Amplicons of GVE were eluted from gels using the ZymoClean Gel DNA Recovery Kit (Zymo Research Corp), quantified, and sequenced using GVE-1-For and GVE-Rev primers by Sanger sequencing at the University of California-Davis sequencing facility (http://dnaseq.ucdavis.edu).

A multiple alignment was produced using the Muscle algorithm (Edgar 2004). A maximum likelihood tree as implemented in Topali v2 (Milne et al. 2009) was constructed to determine the relationship between the isolates sequenced in this study, as well as their relationships to previously reported North American, African, and Asian isolates. Alternatively, an alignment of a shorter 471-nt region from the previous alignment was designed to include only the coat protein (CP) ORF; this facilitated an alignment with the corresponding sequences from more divergent vitivirus species in order to assess the relative position of GVE in this group. Nucleotide sequence diversity was measured, as defined by Nei (Nei and Li 1979), and evidence of selection pressure was evaluated using a Tajima's D (Tajima 1989); both analyses were conducted as implemented in DnaSP (Librado and Rozas 2009).

\section{Results}

A limited survey of viruses in Concord vines in western New York. In order to assess the occurrence of GVE and GLRaV-3 in Concord vines in New York, a limited survey was performed, including samples from production, nursery, and repository vineyards. Of the 46 Concord vines (V. labrusca) tested, 10 (22\%) showed positive signals for hybridization to oligonucleotide probes for GVE in the macroarray assay (Fig. 1; Table 2). Nucleic acid extracts from vines testing positive for GVE hybridized with from 8 to 20 of the $24 \mathrm{GVE}$-specific oligonucleotide probes on the array. The presence of GVE sequences in infected plants was confirmed by RT-PCR followed by direct sequencing of the amplicons. Two additional clones of Vitis spp. from the USDA germplasm repository in Geneva, NY also tested positive for GVE;

Table 1. Origin of grapevine samples tested for viruses in this study

\begin{tabular}{llr}
\hline Collection sites, regions & \multicolumn{1}{c}{ Species } & $\begin{array}{r}\text { Number } \\
\text { of vines }\end{array}$ \\
\hline Western New York & \multicolumn{1}{c}{ Vitis labrusca (Concord) } & 44 \\
USDA NPGS, Plant Genetic & V. riparia & 1 \\
Resources Unit, Geneva, NY & V. hybrid & 1 \\
& V. labrusca (Concord) & 2 \\
University of California, Davis & V. vinifera & 198 \\
$\quad$ Grapevine Virus Collection & & 77 \\
USDA NPGS, National Clonal & $V$. vinifera & \\
$\quad$ Germplasm Repository, Davis, CA & & 40 \\
Foundation Plant Services, & $V$. vinifera & 102 \\
$\quad$ Davis, CA & & \\
Napa Valley, CA & V. vinifera & \\
\hline
\end{tabular}

${ }^{\mathrm{a}}$ USDA NPGS = United States Department of Agriculture National Plant Germplasm System. these were the Vitis hybrid 'Remaily 66-54-2' clone PI588332 and the $V$. riparia clone PI588344 (Table 2). All of the GVE-infected vines in New York also showed positive signals for hybridization to 6 to 25 of the 44 oligonucleotide probes for GLRaV-3. Thus, all GVE-infected Concord vines were coinfected with GLRaV-3, consistent with results from ELISA testing. No other grapevine viruses were detected in this sample of 46 Concord vines.

GVE present in $\boldsymbol{V}$. vinifera cultivars in California. In parallel with the work in New York, 417 California vines ( $V$. vinifera) were screened for the presence of GVE and other viruses by RT-PCR. GVE was detected in eight of the clones (approximately 2\%), all from germplasm and virus collections (Table 2). None of the 102 vines from commercial vineyards tested positive for GVE. All of the GVEpositive vines also harbored between three to six additional viruses, including at least one leafroll virus and one additional vitivirus.

Sequence analysis. To confirm the presence of GVE and assess the sequence diversity among isolates of this virus, a GVE-specific cDNA was amplified by RT-PCR and sequenced directly or after cloning into pGEM-T (Promega Corp.), and a 675-nt region was analyzed. The analyzed cDNA spanned $471 \mathrm{nt}$ of the $3^{\prime}$ end of the $\mathrm{CP}$ gene (ORF4), a 17-nt intergenic region, and $187 \mathrm{nt}$ of the $5^{\prime}$ end of the putative nucleic acid binding protein gene (ORF5) in the genome of GVE-SA94 (nucleotide positions 6,624 to 7,299 in GenBank accession GU903012). All 20 isolates from this study and two described previously (Thompson et al. 2014) were sequenced (GenBank accessions KR062097 to KR062118) and shown to be closely related ( $>98 \%$ nucleotide identity and $100 \%$ amino acid identity) to GVESA94 from South Africa and to form a separate clade from the Asian isolates TvAQ7 and GFMG-1 (GenBank accessions AB432910 and KF588015, respectively; Fig. 2). This study further supports the relationships between vitiviruses (Alabi et al. 2013), showing GVE to be the most distantly related member of the group (Fig. 2A). Additional analyses revealed very low overall nucleotide diversity $(\pi=0.005)$, and a nonsignificant trend toward negative selection $(\mathrm{D}=-1.59$, $0.10>P>0.05)$.

\section{Discussion}

GVE is established in the United States. GVE infection was detected in multiple vines from New York and California; together with a recent report of this virus from Washington State (Alabi et al. 2013), this indicates that the virus is established in the major grape-growing regions of the United States. GVE was observed commonly in

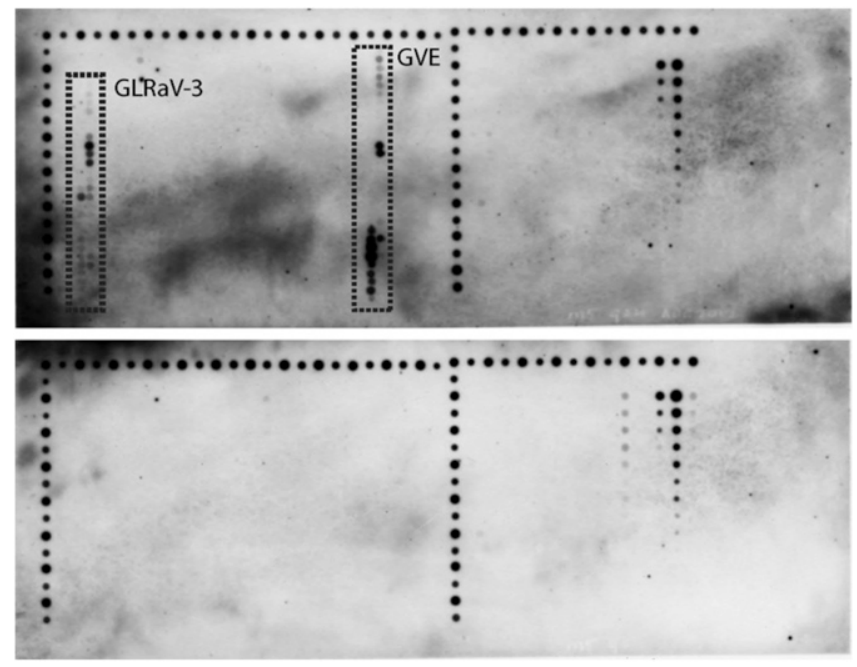

Fig. 1. Macroarray detection of grapevine viruses. Above, a nucleic acid extract from Vitis labrusca 'Concord' sample MacsR97 was purified, labeled, hybridized to the nylon membrane, and resolved as described by Thompson et al. (2014). Boxed areas show sections of the membrane with probes specific to Grapevine leafroll-associated virus-3 (GLRaV-3) and Grapevine virus $E$ (GVE) as labeled). Hybridization signals along the top and in vertical columns are those of the macroarray controls. Below, a macroarray of a negative control nucleic acid extract from the reference Concord vine DC1-1, processed as described above. 
Concord vines in New York, being found in $22 \%$ of the 46 vines tested. The detection of infected vines in commercial vineyards in New York highlights the potential for spread, because these vines represent reservoirs from which the virus could be transmitted to other production vineyards (secondary spread). Although GVE was detected in California, it was seen only in grapevine collections, not in commercial vines. The limited scope of this survey precludes an assessment of incidence or distribution.

Table 2. Mixed infection of Grapevine virus $E$ and other viruses in infected grapevines from New York and California

\begin{tabular}{llll}
\hline Samples & \multicolumn{1}{c}{ Host } & \multicolumn{1}{c}{ Source $^{\mathbf{a}}$} & \multicolumn{1}{c}{ Viruses detected $^{\mathbf{b}}$} \\
\hline New York & Vitis labrusca & Commercial vineyard & GLRaV-3, GVE \\
DAA number 1 & V. labrusca & Commercial vineyard & GLRaV-3, GVE \\
DAA number 4 & V. labrusca & Commercial vineyard & GLRaV-3, GVE \\
DAA number 5 & V. labrusca & Commercial vineyard & GLRaV-3, GVE \\
DAA number 6 & V. labrusca & Commercial vineyard & GLRaV-3, GVE \\
HAA number 9 & V. labrusca & Commercial vineyard & GLRaV-3, GVE \\
DNSP & V. labrusca & Commercial vineyard & GLRaV-3, GVE \\
VD1-1 & V. labrusca & Commercial vineyard & GLRaV-3, GVE \\
MacsR97 & V. labrusca & Commercial vineyard & GLRaV-3, GVE \\
BW3-1 & V. labrusca & Commercial vineyard & GLRaV-3, GVE \\
BH1-3 & V. riparia & NPGS, Geneva & GLRaV-3, GVE \\
10-102 & V. hybrid & NPGS, Geneva & GLRaV-3, GVE \\
5-2 & & & \\
California & V. vinifera & DGVC & GLRaV-3, GRSPaV, GVA, GVE \\
ARM VSV 11 V25 & V. vinifera & DGVC & GLRaV-1, -2, -3, GRSPaV, GVA, GVE \\
ARM VSV 12 V22 & V. vinifera & NPGS, Davis & GLRaV-1, -2, -3, -5, GRSPaV, GVA, GVE \\
K5-56 & V. vinifera & GPGS, Davis & GLRaV-2, -3, GRSPaV, GVA, GVD, GVE \\
K7-57 & V. vinifera & NPGS, Davis & GLRaV-2, -3, GVA, GVB, GVD, GVE \\
K8-45 & V. vinifera & FPS, Davis & GLRaV-2, -3, GVA, GVB, GVD, GVE \\
K8-46 & V. vinifera & NPGS, Davis & GLRaV-1, -3, GVA, GVB, GVD, GVE \\
K8-53 & V. vinifera & NPGS, Davis & \\
K8-59 & SyV &
\end{tabular}

${ }^{\text {a }}$ NPGS = National Plant Germplasm System, DGVC = Davis Grapevine Virus Collection, and FPS = Foundation Plant Services.

b GLRaV-1, -2, and $-3=$ Grapevine leafroll-associated virus-1, -2 , and $-3 ; \mathrm{GRSPaV}=$ Grapevine rupestris stem pitting-associated virus $; \mathrm{GVA}=$ Grapevine virus $A ; \mathrm{GVB}=$ Grapevine virus $B ; \mathrm{GVD}=$ Grapevine virus $D ;$ and $\mathrm{GVE}=$ Grapevine virus $E$.

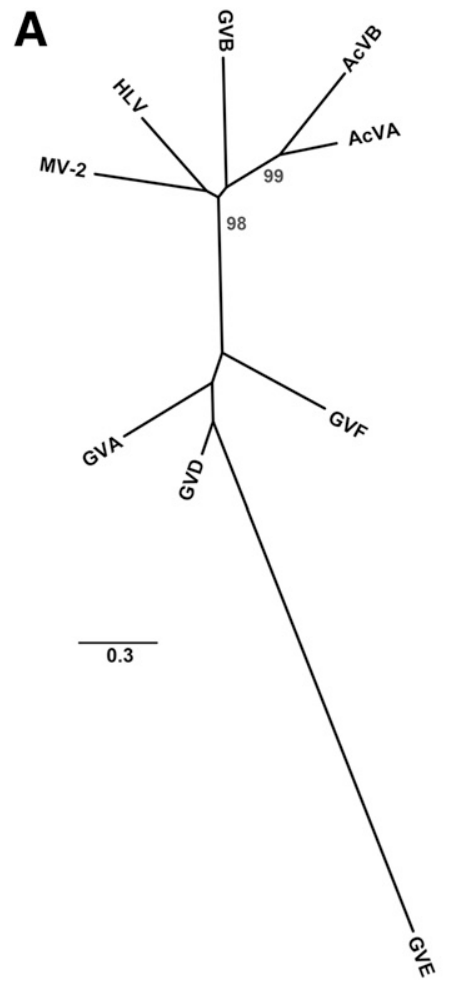

B

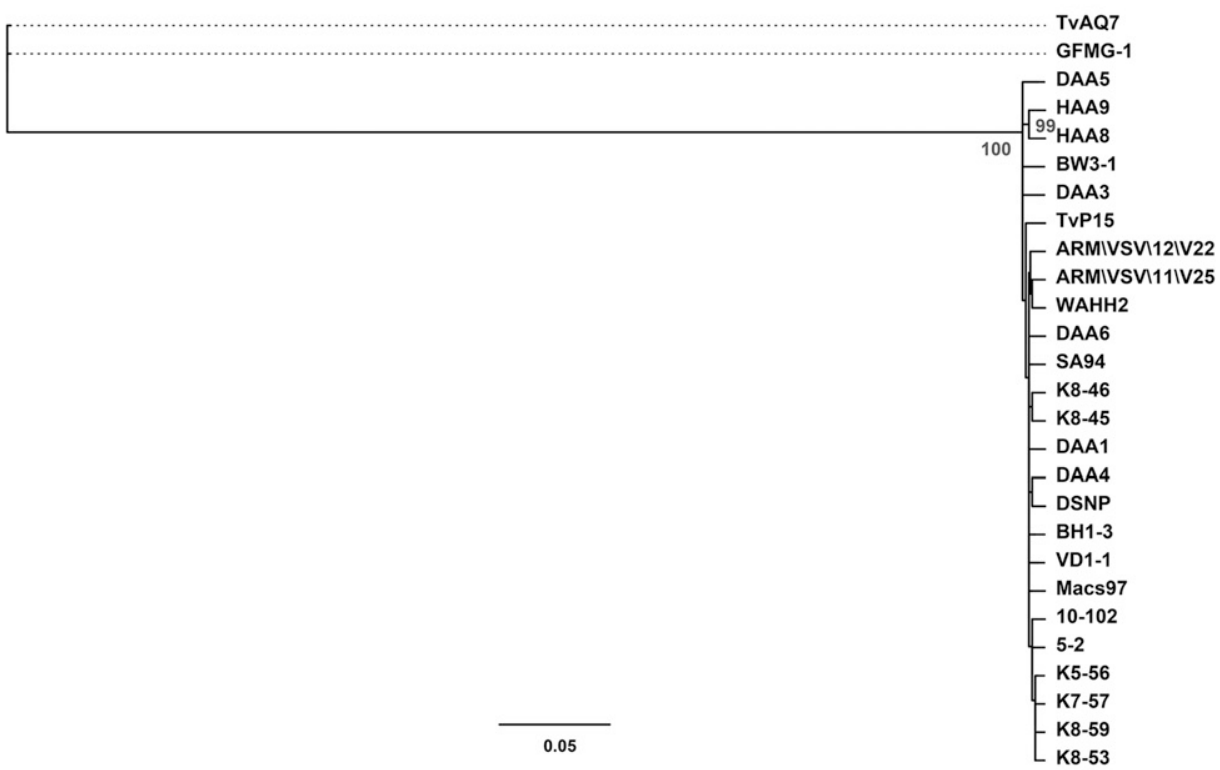

Fig. 2. A, Unrooted maximum likelihood tree (model $\mathrm{K} 80+\mathrm{G}$ ) (Kimura 1980) of a fragment of the coat protein open reading frame showing the evolutionary relationships of vitiviruses. Bootstrap values correspond to 100 repetitions. Only values above 70 are shown. Virus acronyms (and corresponding accession number) are AcVA, Actinidia virus $A$ (JN427014); AcVB, Actinidia virus B (NC_016404); GVA, Grapevine virus A (NC_003604); GVB, Grapevine virus B (NC_003602); GVD, Grapevine virus D (JQ031715); GVE (GU903012); GVF, Grapevine virus F (NC_018458), HLV, Heracleum latent virus ( $\times 79270)$; and MV-2, Mint virus 2 (AY913795). B, Unrooted maximum likelihood tree (model TVMef+G (Posada 2003)) of a 675-nucleotide fragment of the GVE genome showing the evolutionary relationships between GVE isolates from North America, South Africa, and Asia. Bootstrap values correspond to 100 repetitions. Only values above 70 are shown. Isolate acronyms and corresponding accession numbers are GVE-GFMG-1 (KF588015), GVE-TvAQ7 (AB432910), TvP15 (AB432911), GVE-WAHH2 (JX402759), and GVE-SA94 (GU903012). 
GVE host range and effects. GVE has previously been reported as infecting cultivars of $V$. labrusca (Nakaune et al. 2008; Thompson et al. 2014) and V. vinifera (Alabi et al. 2013; Coetzee et al. 2010a). In this study, GVE was detected in cultivars of these two species, and additionally from $V$. riparia and a Vitis hybrid. For GVE (and other vitiviruses), there are no reported hosts or reservoirs outside of Vitis spp. although, under experimental conditions, some vitiviruses can be mechanically transmitted to and propagated in herbaceous hosts (du Preez et al. 2011; Nakaune et al. 2008). GVE was shown to be transmitted by the mealybug Pseudococcus comstocki in Japan (Nakaune et al. 2008). Thus, GVE has persisted in infected vines and has the potential to spread in planting stocks but, at present, there is no indication of spread by mealybugs in North America. Vitiviruses, in particular GVA and GVB, are associated with rugose wood disease symptoms (Goszczynski and Jooste 2002; Habili and Randles 2012; Martelli and Boudon-Padieu 2006; Rosa et al. 2011), although inferring causal relationships through a demonstration of Koch's postulates is lacking for these and most other viruses in grapevine. The extent to which GVE affects vine health and productivity alone or in combination with other viruses remains to be determined.

Genetic diversity of GVE in the United States is limited. The GVE isolates described in this study exhibit limited genetic diversity. A comparison of the GVE sequences from this study with those available in public databases showed U.S. isolates to be very closely related to the SA94 isolate from South Africa (Coetzee et al. 2010b). Worldwide, there are two distinct genetic lineages of GVE among the fully sequenced genomes. One lineage is represented by isolates SA94 from South Africa (GenBank accession GU903012) and WAHH2 from the United States (GenBank accession JX402759). The second lineage is typified by the isolates TvAQ7 from Japan (GenBank accession AB432910) and GFMG-1 from China (GenBank accession KF588015). The nucleotide sequence identity within groups is $>98 \%$ ( $100 \% \mathrm{CP}$ amino acid identity), while identities between groups is only $70 \%$ (87\% CP amino acid identity). Results from this study suggest that only the SA94/WAHH2 genetic lineage is present in the United States, because no isolates similar to the TvAQ7 and GFMG-1 isolates from Japan and China, respectively, were detected. Interestingly, with the recent submissions of sequences of new GVE isolates from China (GenBank accessions KF588017 to KF588034), it is apparent that both genetic lineages are present in this region. The limited sequence identity between lineages of GVE highlights the necessity of using robust diagnostic primers to avoid false negatives in germplasm testing.

The methodologies used to detect GVE in New York and California differed and each have their limitations. The macroarray method is less sensitive than PCR but is relatively robust in detecting virus strain sequence variants (Agindotan and Perry 2007; Thompson et al. 2014). For the GVE isolates detected, hybridization signals were very strong and sensitivity was not limiting. PCR is more sensitive but is sequence specific and may fail to detect sequence variants. After the conclusion of this work, it was brought to our attention that the primer GVE-1-For designed by Coetzee et al. (2010b) has a $3^{\prime}$-terminal mismatch to the second lineage isolates described in the literature (e.g., isolates TvAQ7 and GFMG-1). This might have resulted in a failure to detect some isolates in California but not isolates in New York, where the primary detection method was the macroarray.

All GVE-infected vines are coinfected with other viruses. Concord vines in New York infected with multiple vitiviruses were reported by Thompson et al. (2014). In the present survey, using the same methodology, GVE was the only vitivirus observed in Concord vines, and all GVE-positive Concord samples were also infected with GLRaV-3. An early coinfection of planting stocks commonly used among growers and nursery operations in New York could explain this observation. In a Concord vine survey conducted in Washington state, GVE was not tested for and no vitiviruses were detected but GLRaV-3 was the most prevalent leafroll-associated virus observed (Bahder et al. 2013), consistent with the results from New York. By contrast, in V. vinifera samples from California, infections with multiple vitiviruses were observed, and all GVE-positive samples were coinfected with at least one other vitivirus and a leafroll-associated virus (Table 2). Virus cotransmission among grapevines carried out by mealybug vectors has been demonstrated with vitiviruses and ampeloviruses (Hommay et al. 2008; Le Maguet et al. 2012) and this would result in multiple virus infections, as observed in the $V$. vinifera surveyed in this study.

This study demonstrates that GVE is established in commercial plantings of Concord vines in the eastern United States. Whether GVE is also present in Concord vines in the western United States remains to be determined. This virus was also observed in fieldplanted collections of $V$. vinifera in California but it has not been reported from commercial vineyards. Detection methods based on RT-PCR are currently used to screen for GVE in foundation stocks, and these efforts will help to limit the additional spread of this virus.

\section{Acknowledgments}

We thank participating growers for their cooperation, especially R. Dunst of Double A Vineyards, and anonymous reviewers for their input. Support for this work came from the United States Department of Agriculture Animal Plant Health Inspection Service as part of the National Clean Plant Network, the New York State Department of Agriculture and Markets, the American Vineyard Foundation, the New York Wine and Grape Foundation, and the New York Farm Viability Institute.

\section{Literature Cited}

Agindotan, B., and Perry, K. L. 2007. Macroarray detection of plant RNA viruses using randomly primed and amplified complementary DNAs from infected plants. Phytopathology 97:119-127.

Alabi, O., Poojari, S., Sarver, K., Martin, R., and Naidu, R. 2013. Complete genome sequence analysis of an American isolate of Grapevine virus E. Virus Genes 46:563-566.

Al Rwahnih, M., Daubert, S., Golino, D., Islas, C., and Rowhani, A. 2015 Comparison of next generation sequencing vs. biological indexing for the optimal detection of viral pathogens in grapevine. Phytopathology 105:758-763.

Al Rwahnih, M., Daubert, S., Islas, C., Golino, D., and Rowhani, A. 2014 Characterization of a fifth vitivirus in grapevine. J. Plant Pathol. 96:219-222.

Bahder, B. W., Alabi, O., Poojari, S., Walsh, D. B., and Naidu, R. A. 2013. A survey for grapevine viruses in Washington State "Concord" (Vitis $\times$ labruscana L.) vineyards. Online publication. Plant Health Prog. doi:10.1094/PHP-20130805-01-RS

Coetzee, B., Freeborough, M.-J., Maree, H. J., Celton, J.-M., Rees, D. J., and Burger, J. T. 2010a. Deep sequencing analysis of viruses infecting grapevines: Virome of a vineyard. Virology 400:157-163.

Coetzee, B., Maree, H., Stephan, D., Freeborough, M.-J., and Burger, J. 2010b. The first complete nucleotide sequence of a grapevine virus E variant. Arch. Virol. 155:1357-1360.

Edgar, R. C. 2004. MUSCLE: Multiple sequence alignment with high accuracy and high throughput. Nucleic Acids Res. 32:1792-1797.

Fan, X., Dong, Y., Zhang, Z., Ren, F., Hu, G., and Zhu, H. 2013. First report of Grapevine virus E from grapevines in China. J. Plant Pathol. 95:659-668.

Goszczynski, D. E., and Jooste, A. E. C. 2002. The application of single-strand conformation polymorphism (SSCP) technique for the analysis of molecular heterogeneity of grapevine virus A. Vitis 41:77-82.

Habili, N., and Randles, J. 2012. Major yield loss in Shiraz vines infected with Australian Shiraz disease associated with Grapevine virus A. In: Ext. Abstr. 17th Meet. ICVG, Davis.

Hommay, G., Komar, V., Lemaire, O., and Herrbach, E. 2008. Grapevine virus A transmission by larvae of Parthenolecanium corni. Eur. J. Plant Pathol. 121: 185-188.

Kimura, M. 1980. A simple method for estimating evolutionary rates of base substitutions through comparative studies of nucleotide sequences. J. Mol. Evol. 16:111-120.

Klaassen, V. A., Sim, S. T., Dangl, G. S., Osman, F., Al Rwahnih, M., Rowhani, A., and Golino, D. A. 2011. Vitis californica and Vitis californica $\times$ Vitis vinifera hybrids are hosts for Grapevine leafroll-associated virus-2 and -3 and Grapevine virus $A$ and $B$. Plant Dis. 95:657-665.

Komar, V., Vigne, E., Demangeat, G., and Fuchs, M. 2007. Beneficial effect of selective virus elimination on the performance of Vitis vinifera $\mathrm{cv}$. Chardonnay. Am. J. Enol. Vitic. 58:202-210.

Le Maguet, J., Beuve, M., Herrbach, E., and Lemaire, O. 2012. Transmission of six ampeloviruses and two vitiviruses to grapevine by Phenacoccus aceris. Phytopathology 102:717-723

Librado, P., and Rozas, J. 2009. DnaSP v5: A software for comprehensive analysis of DNA polymorphism data. Bioinformatics 25:1451-1452

Maliogka, V. I., Olmos, A., Pappi, P. G., Lotos, L., Efthimiou, K., Grammatikaki, G., Thierry, C., Nikolaos, K., and Apostolos, A. 2015. A novel grapevine badnavirus is associated with the Roditis leaf discoloration disease. Virus Res. 203:47-55.

Maree, H. J., Almeida, R. P. P., Bester, R., Chooi, K. M., Cohen, D., Dolja, V. V, Fuchs, M., Golino, D., Jooste, A., Martelli, G., Naidu, R., Rowhani, A., 
Saldarelli, P., and Burger, J. 2013. Grapevine leafroll-associated virus 3. Front. Microbiol. 4:00082.

Martelli, G., and Boudon-Padieu, E. 2006. Directory of infectious diseases of grapevines and viroses and virus-like diseases of the grapevine: Bibliographic report 1998-2004. In: Opt. Méditerr. Sér. B. Etud. Rech. E. Martelli, P. Giovanni, and E. Boudon-Padieu, eds. CIHEAM, Bari, Italy.

Martelli, G., Ghanem-Sabanadzovic, N., Agranovsky, A., Al Rwahnih, M., Dolja, V., Dovas, C., Fuchs, M., Gugerli, P., Hu, J., Jelkmann, W., Katis, N., Maliogka, V., Melzer, M., Menzel, W., Minafra, A., Rott, M., Rowhani, A., Sabanadzovic, S., and Saldarelli, P. 2012. Taxonomic revision of the family Closteroviridae with special reference to the grapevine leafroll-associated members of the genus Ampelovirus and the putative species unassigned to the family. J. Plant Pathol. 94:7-19.

Martelli, G. P. 2014. Directory of virus and virus-like diseases of the grapevine and their agents. J. Plant Pathol. 96:1-136.

Milne, I., Lindner, D., Bayer, M., Husmeier, D., McGuire, G., Marshall, D. F., and Wright, F. 2009. TOPALi v2: A rich graphical interface for evolutionary analyses of multiple alignments on HPC clusters and multi-core desktops. Bioinformatics 25:126-127.

Nakaune, R., Toda, S., Mochizuki, M., and Nakano, M. 2008. Identification and characterization of a new vitivirus from grapevine. Arch. Virol. 153: 1827-1832.

Nei, M., and Li, W. H. 1979. Mathematical model for studying genetic variation in terms of restriction endonucleases. Proc. Natl. Acad. Sci. 76:5269-5273.
Posada, D. 2003. Using MODELTEST and PAUP* to select a model of nucleotide substitution. Chapter 6, Unit 6.5.1-6.5.14 in: Current Protocols in Bioinformatics, John Wiley \& Sons, Hoboken, NJ.

du Preez, J., Stephan, D., Mawassi, M., and Burger, J. 2011. The grapevineinfecting vitiviruses, with particular reference to grapevine virus A. Arch Virol. 156:1495-1503.

Ramsdell, D. C., Bird, G. W., Gillett, J. M., and Rose, L. M. 1983. Superimposed shallow and deep soil fumigation to control Xiphinema americanum and Peach rosette mosaic virus reinfection in a Concord vineyard. Plant Dis. 67:625-627.

Rosa, C., Jimenez, J. F., Margaria, P., and Rowhani, A. 2011. Symptomatology and effects of viruses associated with rugose wood complex on the growth of four different rootstocks. Am. J. Enol. Vitic. 62:207-213.

Soule, M. J., Eastwell, K. C., and Naidu, R. A. 2006. First report of Grapevine leafroll associated virus-3 in American Vitis spp. grapevines in Washington State. Plant Dis. 90:1461.

Tajima, F. 1989. Statistical method for testing the neutral mutation hypothesis by DNA polymorphism. Genetics 123:585-595.

Thompson, J. R., Fuchs, M., McLane, H., Celebi-Toprak, F., Fischer, K. F., Potter J. L., and Perry, K. L. 2014. Profiling viral infections in grapevine using a randomly primed reverse transcription-polymerase chain reaction/macroarray multiplex platform. Phytopathology 104:211-219.

Uyemoto, J. K., Taschenberg, E. F., and Hummer, D. K. 1977. Isolation and identification of a strain of grapevine Bulgarian latent virus in Concord grapevine in New York State. Plant Dis. Rep. 61:949-953. 